\title{
The church and diaconia as local partners in the social space: Challenges and opportunities
}

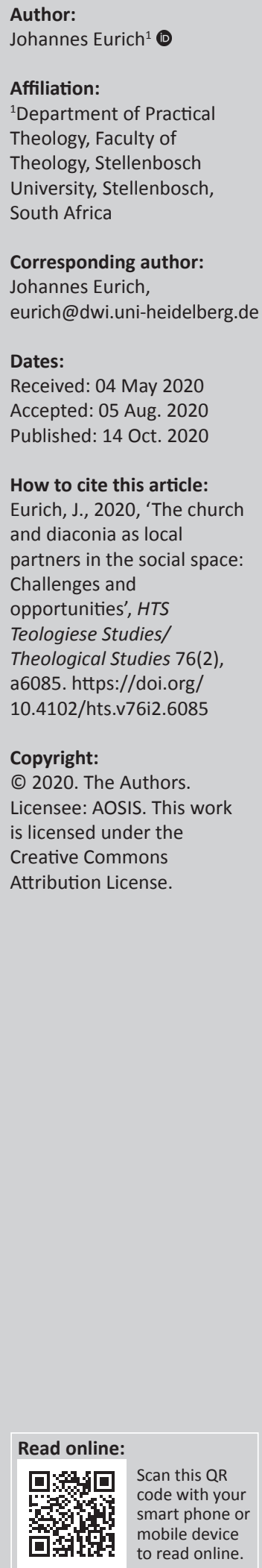

Demographic change, change in family structures, growing ethnic plurality resulting from migration, social inequality and so on require new ways of addressing spiritual and social needs in many Western European countries. In view of these current social changes, increasingly more effort is being put into strengthening cooperation between church congregations and diaconal institutions at the local level. This article will focus on the reciprocal relationship between the church and its immediate local context by focusing on one of the church's ministries - diaconia - as a service of God's people to the world. Although diaconia is part of the church, it has developed in organisations separate from the church and thus as a parallel structure to the institutionalised church structure in many countries. The current changes offer opportunities for the church and diaconia to join forces and to overcome cooperational difficulties at the local level. The objective of this article is to draw attention to the potential of the social space for collaboration, to analyse hindrances to collaborative efforts on a practical level and to point out what steps the church and diaconia may take to further local collaboration.

Contribution: The contribution of this article is to analyse the social space with regard to the collaboration between local churches and diaconal organisations, and thereby to point out its potential for their further development in line with the journal's focus on original ideas in practical theology.

Keywords: Social space; Community development; Local church; Diaconia; Participation; Social context.

\section{Introduction}

Mainline churches are experiencing a sharp decline in numbers in many European countries and are being challenged to find new possibilities for reaching out to people. In particular, local congregations are no longer at the centre of communal life but have lost this position. There is a need to get to know the people outside of the church walls and to redirect the activities of local churches to serve the spiritual and social needs of these people. New approaches are to be developed in order to create a specific network of cooperation partners from local churches, diaconal institutions and others like local shops/economy, other welfare organisations, the municipality and civil society actors towards the common good in the local space. This development is very relevant for both diaconal institutions and local churches. On the one hand, diaconal institutions like care centres or stationary nursing homes are challenged to respond to changes in social fields of action. For instance, 'inclusion' and 'participation' are only two buzzwords in which spatial references are of decisive importance. In the same way - as a possible strategy for coping with demographic change - the health policy-driven outpatientisation of medical and nursing services is driving the set-up of a local support network of counselling services, volunteers, self-help groups, hospice groups, neighbourhood help and so on at the expense of stationary institutions. In many European countries, social politics also support the promotion of ambulant care settings in the local area (multigenerational houses, family centres, volunteer centres, etc.). Diaconal institutions are challenged to redirect their services according to these developments. On the other hand, local churches in many Western European countries are shrinking, some to the point where they are closed or reorganised as part of a larger unit of former local churches, thereby losing touch with the local people. In order to touch people's lives, churches have to find new ways - how to be a relevant partner for the people. One approach is to become engaged in social space networks as a local church. These developments point to the increased importance of defining and shaping the social space. Therefore, I will concentrate on the definition and the social texture of social spaces in my first section (cf. Sandu \& Ioan 2013). 
How can cooperation in the social space be shaped? The different organisational structures of the church and diaconia and the resulting difficulties create challenges in cooperating that will be analysed in the second section. Pragmatic aspects of sociospatial commitments are discussed in the third section, and possibilities for cooperation between the church and diaconia are highlighted. Finally, the outlook indicates what the follow-up steps will be for the church and diaconia to become involved in social-spatial activities.

\section{Understanding social spaces}

The term 'social space' refers to the social context 'mediated or defined by a territorial reference (district, neighbourhood), interests and functional connections (organisation, housing, work, leisure) or categorical affiliation (gender, ethnicity, age)' (Stövesand \& Stoik 2013:14-36). Social spaces are characterised by a spatial delimitation, which, of course, only provides the ground for balancing the different interests and goals of the people living in a social space. In the social space, no central principle has been valid for a long time (cf. Sigrist 2014:329). Rather, social spaces differentiate themselves further on the basis of overall social megatrends such as pluralisation, demographic change and migration, so that a plurality of values, cultures and life plans of individuals and groups coexist in a social space.

The changes in the profile of the social space also affect church congregations: They are subject to the manifold dynamics and processes of change in society, which are reflected locally in the gentrification of entire city districts, in the agglomeration of the world of work and living, or in the medialisation of the virtual and real worlds (cf. Sigrist 2014):

These different dynamics and complex changes often do not run linearly and appear, for example, where church buildings suddenly no longer stand 'in the middle of the village' or 'in the neighbourhood'. The 'village' as a Christian shaped place of social closeness has departed from church life by the fact that the majority of the inhabitants around the church are persons with a different cultural or religious background. (p. 329)

Whereas in the past the church was the centre of the village or the district, not only in the geographical sense but also as a necessary spiritual dimension of social life, the Christian community nowadays plays less of an important role. This can be seen in the sale or demolition of church buildings today. The spatial allocation structure of a Christian majority of the population to its parochial congregation - as it was especially the case in many Western European countries for a long time - is undermined today by two factors: (1) the dwindling membership base of the church and (2) changes in the social spaces around the congregations. As a consequence, the spatial structure of parishes can no longer be adequately related to its social context, because social contexts have long since become very heterogeneous. The demolition or sale of the church building is more and more often the sad end of a specific local church. What is the place of the church in the neighbourhood today when it is still located in the centre, but does no longer play a central role?

\section{Local presence of the church in the social neighbourhood}

In the middle of the social space, the church as a public presence of Christian faith has been given an unusual assignment of place: 'No placelessness, but a place in between' (Grözinger 1998). A place between immanence and transcendence, between God and human, between inside and outside, between privacy and publicity - this in-between is a marker for the multidimensionality of human existence. It is a point of orientation for newly gained insights about the local presence of the church. There are no longer clearly defined parochial borders but rather blurred and distorted places in the context of multiculturally and religiously plural developing communities (cf. Sigrist 2014:328). It may even be necessary to note that church congregations 'function indefinitely and orient themselves diffusely in this public space of "in-between": (...) The blurriness of the experience of social life forbids sharp demarcations of municipal structures', says Sigrist (2014:328).

The assignment and the development potential of church congregations in the social space are consequently seen precisely in this diffuse localisation of the in-between: As 'intermediary institutions' (Schlag 2012:45-48), their signum lies between the different functions and interests of other social players and institutions. It is important to note that the religious dimension cannot be separated from civil society commitment. Religious narratives like the Good Samaritan lead to a sensitivity for social contexts and emergencies. They focus on the ones who need help, not only in spiritual matters but also in practical ways. Thus, one function of religious communities in these public spaces in between is to keep religious narratives present and to communicate them, thus motivating people to commit themselves to helping others (Brager \& Specht 1973).

To shape the spheres of social space in the sense of a culture of care, to establish interpersonal relationships through the different church actors, resources and spaces will more and more (have to) determine the development of local churches as well as of church places (including diaconia) in society. At this point, it may be necessary to mention that local churches may not have all the resources and expertise to move in this direction. In many countries, diaconal organisations that specialise in helping people with specific needs are part of the church. Although these diaconal organisations are theologically identified as one of five ministerial activities of the church, some of them have become professionalised service providers that operate according to the logics of social markets and professional standards. Their connection to the church has been reduced to institutional links, so that there is a discussion about the diaconal profile of such market-oriented diaconal organisations. I cannot address 
this discourse here (cf. Eurich \& Maaser 2013). However, I point out that the social space offers opportunities to strengthen common efforts by local churches and diaconal service providers to work together. As a side effect this may also help diaconal organisations to be more easily identified as a church-based organisation and to develop correspondent elements.

The formation of church congregations can in future take on new forms of organisational development, if the (local) church understands herself as an intermediary force and takes into account impulses of the local social area. This new form is more like a network structure building upon Christian grassroots communities and new initiatives so that the church can react to the urgent needs of people, thereby addressing with the Gospel spiritual issues according to the contextuality of the social space. It is important that the church hereby shows attention to non-conformity - inclusion of different marginal groups into community life - for this is one of the callings of the church (De Roest 2013:81). The decline of parishes is only one direction of development-simultaneously more and more new church 'places' will emerge.

'The different forms of congregations, which have a variety of effects on the social local area, are correspondingly different and plural' (Sigrist 2014:329). Church congregations and social local areas influence each other mutually (Sigrist 2014):

Congregations with their spaces in the best locations, their networks of volunteers and their stagings of counter-worlds on the spot (...) set impulses in the local area. In the same way, food areas with their inns, hostels, public gardens and squares, promenades and shopping streets shape the face of the communities. (p. 329)

The initial question for development strategies therefore starts with the resource potential, which is given by the contextuality of the social space: 'What can we mean for each other?' (De Roest 2013:84).

\section{Consequences for the local church}

In North Amsterdam, 3 out of 10 churches were abolished between 1980 and 2010. Since 2010, however, six 'new church locations' have emerged again; new, even fuzzy forms of congregations have come to life in the contextuality of the respective social spaces. De Roest cites the example of the Oranjekerk in De Pijp: 'It turns out that the modern pastor in practice also does "community work"' (De Roest 2013:84). It starts by learning to look at a village or a neighbourhood with new eyes in order to discover what meaning the church could have for the community, and vice versa - how the neighbourhood can become a resource for the church. For De Roest, even the situation that actually marks the end of parochial life, when the critical limit of membership or financial resources is reached, has the potential to be a catalyst to see the environment with new eyes, tear down an existing structure and create a new one' (De Roest 2013:84).
The emerging new church locations are characterised as (Sigrist 2014):

[A] dynamic, heterogeneous biotope of passing and growing auxiliary, learning and festive communities of believers who call themselves Christian. These local churches are formed in the midst of a social space experienced as a sphere, networked with different life worlds. (p. 333)

There are a lot of questions to be discussed with regard to this development. From a theological perspective, the church is not to become a civil society organisation that is run according to the expectations of the civil population. Rather, it has to stay true to God's mission. On a more practical note, traditional mainline churches lose touch with the people and are experiencing dramatic losses in membership. Yet, they are still involved in the communal sphere through their institutional links and forms of ministry like diaconia. The initial question then is how the profiles of a social space and the local church within this space can be related to each other in such a way that places of jointly designed social life are formed in which the church is part of communal activities and can use this avenue to serve people in their practical and spiritual needs. In order to form such new church locations, local churches and diaconal service providers are to join forces, because often local churches do not have the resources for expanded services in the social space. Together, they need to network with other civil society groups as well. In a communal network they can provide a spiritual ministry as their specific expertise, staying true to God's calling in this way. Yet it seems that 'new church locations' face specific challenges when it comes to cooperation in local networks. In the next sections I will only focus on the relationship between local churches and diaconal organisations in order to understand their reciprocal relationship better. If this relationship can be strengthened on practical terms, it may serve as a basis for wider networking within the civil society. This leads us to the question I will try to answer in the next section, namely, what are the differences between a local church and a diaconal service provider from an organisational perspective?

\section{Practical observations}

I would like to begin this section with a question: Why has the cooperation of church congregations and diaconal service providers in the social sphere been a recurring theme for more than 50 years? In practice it often looks like what Amrhein (2016) generally notices when it comes to civil society cooperation:

1. Collaborating in networks is a widely recognised and practised working structure. The willingness on paper to exchange and cooperate, however, has little impact in daily practice, or is limited to rare meetings that have hardly any effect.

2. The funding of projects with a limited duration raises the question of their sustainability. After the end of financial support, precious experiences and insights get lost and disappear, and one would have to start all over again (p. 28). 
Amrhein brings this up in the context of cooperation between citizens, communes and economy in the social space, but in my opinion it applies just as much to church and diaconia. Despite all intentions to the contrary, cooperation often takes place only to a very limited extent and then mainly through projects. 'Fit im sozialen Nahraum' ${ }^{1}$ was a joint initiative of the Evangelical Lutheran Regional Church in Bavaria and various diaconal organisations in Bavaria. Seventy projects were supported and presented. Similar reports can be found in other countries. And yet: Why do these projects need to be carried out for something that should be taken for granted? Because according to our theology, diaconia is part of the church. These special programmes show that cooperation but it has to be initiated specifically by a programme or it may often not happen at all. And after the end of the programme, unfortunately, only a small number of projects succeed in putting the commitment begun with on a permanent footing. Many projects end with the deadline of the funding for the project.

What is the reason for this? From the outset, I would like to exclude moral or otherwise connoted allocations, such as the pastors were not interested enough or the diaconal organisations would first ask only for business profits and so on. Rather, functional differentiations seem to make up a considerable part of the different orientations of church congregational and diaconal work and thus of the difficulties in cooperating with each other. Two quotations from empirical studies illustrate this. One church member noted on the collaboration between her local church and a diaconal service provider:

This certainty with which they come, with personnel and people; they take everything first and foremost, they engage in topics, about which we have been thinking for years. Ask us, do it together with us - and that doesn't happen. They think they know everything right from the start and thus stir up a district. ${ }^{2}$ (p. 18)

A minister reports in view of the cooperation with full-time professionals from another diaconal service provider (Horstmann \& Neuhausen 2010):

One difficulty with the cooperation with the congregation is that the visions the full-time professionals can develop due to their profession have often exceeded what I could take responsibility for as the minister of the congregation. (p. 29)

Both quotations point to the practical difficulties of cooperation between the parish and diaconal work. If one examines the examples of well-functioning cooperations, it turns out that it is predominantly individuals who initiate such cooperations and that for the success of a cooperation, the 'ability to engage with different ways of thinking, decision-making systems and interests' (Hofmann 2016:226) is essential.

\section{C.. Nürnberg 2016}

2.This is a statement of a committed person from a church parish commenting on a new local project of a diaconial organisation in the context of their district's strategy to intensify outpatient treatment, quoted according to Inklusion nebenbei. Menschen mit Beeinträchtigungen im Stadtteil, 2016, published by the Institute of Menschen mit Beeinträchtigungen im St
Social Sciences of the EKD, Hannover.

\section{Local church and diaconal service provider - Two different types of organisations in the social space}

The church and diaconia follow different logics and have diverging goals for their organisational action. In order to better grasp and understand this, different descriptions of the church and diaconia shall first be sketched out, whereby in addition to theological images a sociological external perspective is taken up, before the consequences of these differences are presented.

The church is described as a living organism that survives off the fact that many Christians participate and volunteer - the theological images of the body and priesthood of all believers are guiding here. In social science one could speak of communities in this case. There are relatively few full-time workers, so that congregations follow the logic of a volunteer organisation. As far as possible everyone should be involved and no one should get lost, in part because the members of the body can react sensitively, not only in internal processes, for example when it comes to questions concerning church buildings, but also when the members are irritated, for example because of scandals like the cases of child abuse in the church; at such times, many people lose trust in the organisation and resign from church membership. Members belong to organisations; church organisations are characterised by membership logics. The principle of participation leads to the fact that many different committees are involved in church-organisational decision-making processes, some of which can thus take a long time. The grace of God is proclaimed programmatically and is given free of charge. Love is understood in an overflowing way, which must not be calculated: when you give, the left hand should not know what the right hand is doing. Here, we can speak of the church as an institution: Institutions describe binding rules of communication and action that have attained permanence and stability. For some years there have been approaches in practical theology to depict these different dimensions of church life: the church as an institution, organisation, interaction and a production (Hermelink 2011:89) or the church as an institution, organisation and a community or a movement (Hauschildt \& Pohl-Patalong 2013:216ff). These approaches describe the transformation of the social forms of religion.

Diaconal organisations as social service providers can be assigned to the type of a service organisation. Here, professional standards dominate the action. Efficiency, effectiveness and output are the guiding criteria. There are also many volunteers, but in terms of numbers the employees are more. For this reason, explicit contracts also regulate cooperations to a much greater degree. Internally, the logic of non-profit organisations applies, which have to integrate different stakeholders and the impulses from three sectoral areas, namely the state, the market and civil society. Competition, economic power and strategic positioning are 
decisive markers in the social market. Decision-making processes can be hierarchically or decentrally structured, following efficiency considerations. In addition to the corporate level, however, there are other levels of diaconal involvement.

In social sciences, institutions, organisations and movements differ primarily in their relation to the market (Böckel 2016:93). Markets can be economic markets, but they do not necessarily have to be - for example they also include democracy as a form of competition for the best political solution. The decisive difference between institutions, organisations and movements lies in their relationship to the market (Böckel 2016):

Institutions in the sense of the term separate themselves from markets through the internal lack of consequences of their decisions, movements separate themselves from them through the voluntary provision of services by their members. Organisations, on the other hand, are responsive to the feedback of the market around them, thus they are environmentally responsive. (p. 93)

These differences can be illustrated in this way: A baptism is an institutional act of the church even if, for example, only a few people take part in it besides the minister - the person being baptised, the godfather of the baptised person and a family member. The lack of resonance does not change the institutional programme: The next time a baptism will also be offered. Obviously, what constitutes the institutional action is not made directly dependent on the approval or rejection of the environment. This is different for organisations: If there is no or too little demand for a service provided by a diaconal agency, it will sooner or later be abolished. A high degree of environmental responsiveness is generally given here. The market response is a decisive aspect in the management of the organisation, which determines the target and order orientation and enables it to develop innovations (Böckel 2016:93).

In many countries of Europe, mainline churches today are shifting from being institutions to becoming organisations. This can meanwhile even be seen in job offers for ministers, in which the managerial shares are increasing. It is important that this changed form of church does not retreat into communities of convictions, but maintains its social commitment to marginal groups, the needy, the socially disadvantaged and thus acts as a public actor. In short: the church is becoming more diaconal!

The new church places described above, for example in Amsterdam, but also in Cape Town, Frankfurt or New York, seem to connect precisely these elements: They represent innovative approaches that implement the church's mission as an experiential community in the context of a social space by responding to people's needs and networking with other actors, for instance in interfaith relationships (Körs \& Nagel 2018). In this Böckel (2016) sees the church's future potential:

In any case, environmental responsiveness as well as the ability to innovate increase, the church appears with its 'mission', and concretizes herself as an experiential community. This organisational hybrid is also able to participate in networks or to steer such networks. (p. 117)

'Network' is a keyword that will occupy us more with the next point: the networking of church and diaconia as well as with other partners within the social space.

\section{Pragmatic aspects of social space- based engagement}

In the following section, I will present pragmatic steps that are to be reflected upon when engaging in the social space.

\section{Networks}

Social spaces are characterised by a high degree of diversity and a multitude of different actors who network with one another to pursue specific goals. From a social science perspective, networks are based on selective connections (edges) between several elements (nodes), which may form in a certain pattern (Holzer 2010:34). Networks can also be described as hybrid forms of formal and informal ties that have an undefined or open edge, which facilitates access to them (Böckel 2016):

They combine the contradictory logics of goal- and purposeorientation of organisations in the sense of the term and the membership of communities. They arise essentially from the pursuit of common interests. (p. 98)

This description can easily be transferred to church and diaconia: 'Church as well as diaconia possess on all levels of management both forms of inter- and intraorganisational network structures, which are connected in each case with interpersonal networks' (Böckel 2016:106). What is crucial now is not only to bring these different networks into the social space, but also to relate them to the context of a social space and the needs that arise within it. One's own programmes and the resulting interests must therefore be aligned with local conditions and adapted to them.

\section{Needs orientation}

The starting point for social-spatial planning and action is the needs of the people in the social space. The institutional programme no longer sets the agenda. This is a challenge for church congregations, because no longer are theological 'programmes' the starting point, and no longer are all church bodies included in the control. This challenge also applies to diaconal agencies, which must learn to tread new paths with unsecured financing off the beaten track of social law. The development of social innovations shows how difficult this can be (Langer, Eurich \& Güntner 2019). For networking in the social space, it is crucial to react to local 
needs. If the needs are eliminated, the purpose of the cooperation can be oriented towards new goals, or the cooperation expires.

\section{Organisational form}

Based on the needs of the social environment, logical organisational elements gain importance. 'Leading and controlling in networked relationships therefore takes place, as in organisations, by means of goals and from an environment-related mission' (Böckel 2016:136). From the point of view of sociospatial networks, it is therefore decisive that the internal church perspective be opened up so that interorganisational networks can emerge that are characterised by high dynamics and innovative power, often forming a kind of 'church of the future' workshop of ideas from which new forms of design are developed in an environmentally sensitive or context-related way (Böckel 2016):

The same applies to new forms of congregation which, for example in the case of 'fresh expressions of church', often contain strong diaconal focal points and, especially in the urban context, already form independently of church control systems. (148f)

\section{Cooperation instead of competition}

In principle, this is the other side of the above-mentioned needs orientation. Cooperation in the social space fails if the actor does not focus on the specific needs of the people in the social space, but on their own (organisational) interests in cooperation. Engagement is authentic when it is perceived for the sake of people, not for the purpose of a new business model or trying to gain further market share (Böckel 2016):

This means that a tactical reference in terms of intention, interest and task is not an option, as this would immediately be seen as untrustworthy and would therefore lead to withdrawal from the network. (p. 145)

Haas reflects on the implementation of sociospatial concepts and writes in view of the experiences gained: 'Whoever invades a neighbourhood with a takeover mentality will quickly experience the power of informal networks as a demarcation line' (Haas 2012:261).

\section{Decentralised decision-making autonomy}

Each social space has its own setting; no district or neighbourhood is like another. This is the reason why social spaces require a high level of decision-making autonomy on the ground level. Because of the different partners and their interests and because of the high contextuality of each social space, decisions have to be made by the actors involved on the local level (Böckel 2016):

Networks that refer to relatively autonomous, self-regulating actors rarely stop at the boundaries of a meta-organisation. Common interests, concerns, tasks and goals often lead to the creation of networks that connect actors from inside and outside the church who are very differently involved in the organisation. (p. 107)
In addition to diaconal agencies, there are other partners in the social space who are to be won over for cooperation, but who also represent their own interests in the cooperation. It is possible that their interests will come into conflict with those of the church as an institution. ${ }^{3}$ Here, the local actors must be able to make decisions; otherwise, decision-making processes in the network are not effective. In social spaces there is a high degree of purposeful mobility, which requires autonomous decision-making by the actors in the network structures. For both the church and diaconia, social space cooperation raises the question of decision-making structures: Can local actors like laypeople act relatively autonomously in networks?

These considerations have underlined the point that above all, a social form is suitable for cooperation between church and diaconia (and possibly other actors) in the social area (Böckel 2016):

In view of a common mission, common concerns and common objectives, the network appears for many to be the ideal form of internal cooperation between church and diaconal actors, but also with regard to external non-profit actors. (p. 155)

The resulting control requirements are to be indicated in conclusion in terms of aspects.

\section{Outlook: Next steps for the church and diaconia}

Which indications can be taken from the previous considerations for the organisation of the cooperation of the church and diaconia in the social area? Some aspects will be briefly outlined next.

\section{Competition in networking}

According to Böckel (2016):

Even in a church or diaconal context, the plausibility of networking is (therefore) always high when actors first of all find themselves in an increasing market situation with regard to their environment (...). (p. 130)

This situation is determined both by the social megatrends mentioned above and by local conditions, for example competition for attention, donors, volunteer time and so on. There is more and more competition for sustainable models for social spaces in view of the challenges of demographic change. The pack is being reshuffled socially, and the first alliances and new actors are already in the starting blocks or on the field. Church congregations must be ready to interact with others and not only to keep to themselves (Prendergast 2000). At the same time, they need to know their limits and reassess their resources.

\section{Social spaces are different}

Joint activities tie in with the initial conditions of local contexts and develop tailor-made solutions. Whether these

3. Böckel $(2016: 107)$ states 'that these networks conflict with the steering ability and possibility of the meta possibility of the meta organisation. This gets the more problematic the more selfevident the institutional logic becomes. For the church in general, it is still true that 'the self-conception of the organisational logic is in general only vaguely developed' (Böckel 2016:115) 
are local self-organisations through multifunctional village centres or new forms of networking between kindergardens and centres for the elderly or similar depends primarily on local conditions. Difficult negotiation processes have to be accepted here. The quest for appropriate actions does not begin with the existing resources of diaconia and church, but with the perception and description of local needs, independent of the interests of the organisations. The latter must also be served, but only indirectly. Here, diaconia must take new paths, open itself up to forms of social startups and specifically develop and promote social intrapreneurship, specifically the release of its own employees for the development of new business models, within its own ranks. On the church side, the commitment to the common good must be recognised in its opportunities for communicating the Gospel. Nevertheless, there should be no hidden interests, such as winning more church members - it is all about the needs of the people in the neighbourhood.

\section{Cooperations}

Cooperation is promising when 'certain, moderately specific services for oneself or others can only be achieved through a pool of resources together with other actors' (Böckel 2016:130), which otherwise could not be achieved on one's own. Others also do good work - this must be acknowledged, included, not repressed. Therefore, win-win situations have a high priority. Such cooperations require an opening of one's own organisation to the outside world in the sense that not only contacts and links with other actors take place, but also in the sense that one opens oneself to other interests and action logics; decision-making powers are transferred and networks are given a certain autonomy in decision-making issues because social spaces show a high degree of purposeful mobility.

\section{Specific values}

Churches as well as diaconal organisations operate on a specific Christian value base. Even though the specific needs of a given social space are decisive for social-space engagement (and not their own religious interests), it is necessary that their religious outlook be clearly visible and inform their actions. Otherwise, the church or diaconal organisation is in danger of becoming a mere social service agency. Therefore, specific activities have to be offered in order to equip professionals and laypeople to communicate religious affiliations as well as to develop a Christian organisational culture. The balance between a particular value orientation and the promotion of the common good has to be sought after continuously.

\section{Further education needed}

Cooperation between diaconia and church in the social space requires new training modules (De Roest 2017:275288). The path to education, further training and further education in the sense of a 'pioneering type of leadership which aims at the foundation of new organisational units such as congregations in a secular environment (start-up)' must be reflected practically and theologically. In particular, the connection between 'theology and (social) entrepreneurship' (Böckel 2016:160f) is becoming more significant. Prospective ministers could benefit a lot from diaconal leadership experience, and future diaconal boards of directors and community leaders could be trained together with a view to new forms of cooperation in the social sphere.

Finally, I will take up the example of Ralf Kötter in Germany, who successfully established networks in rural regions and showed an approach that could work. Kötter (2015) writes:

Under the umbrella of a church congregation, a vital competence network has emerged in which all social actors such as politics, business, education or social welfare work pull together, pool their competences and resources and exchange and enrich each other. (p. 22)

If one takes a closer look at Kötter's example, one discovers how strongly diaconal fields of work are integrated into this network under the umbrella of the parish. The activities range from a wide variety of offers in working with children and young people to family counselling and mobility support to working with the elderly, including the organisation and support of the work of volunteers by a deacon church worker (Kötter 2015:194) and intermeshing the work of the church council with that of the 'Gemeindebeirat' (Kötter 2015:160ff) - a local committee to which two members of the church council belong, together with representatives of the local political level, various civil society institutions and four representatives of the accompanying secondary office (Kötter 2015:191211). Upcoming '(...) projects are discussed at all levels and connected in practical implementation' (Kötter 2015:161). This example is encouraging. The church can change and, together with diaconia, will find innovative answers to social challenges in a neighbourhood or region (Halbe 2016):

This will not only achieve a close connection between church life and action and the conditions and concerns of the community as a whole; it will also show what contributions the church community can make to the development and expansion of lifeserving structures and which internal organisation of its work is the most suitable in this respect. (p. 27)

\section{Acknowledgements Competing interests}

The author declares that he has no financial or personal relationships that may have inappropriately influenced him in writing this research article.

\section{Author's contributions}

J.E. is the sole author of this research article. 


\section{Ethical considerations}

This article followed all ethical standards for research without direct contact with human or animal subjects.

\section{Funding information}

This research received no specific grant from any funding agency in the public, commercial or not-for-profit sectors.

\section{Data availability statement}

Data sharing is not applicable to this article as no new data were created or analysed in this study.

\section{Disclaimer}

The views and opinions expressed in this article are those of the author and do not necessarily reflect the official policy or position of any affiliated agency of the author.

\section{References}

Amrhein, U., 2016, 'Die neu entdeckten Nachbarn: Was Bürger, Kommune und Wirtschaft vor Ort bewegen können', in Diakonie Texte, pp. 28-29, 05, Diakonie Deutschland, Evangelisches Werk für Diakonie und Entwicklung e. V., Evangelischer Bundesverband, Berlin.

Böckel, H., 2016, Grundlagen der Führung in kirchlich-diakonischen Netzwerken: Praktisch-theologische Perspektiven auf dem Weg zu einer integrierten Netzwerktheorie', in W. Nethöfel, H. Böckel \& S. Merle (Hrsg.), Vielfältige Vernetzung: Hinauswachsen aus der Volkskirche, pp. 77-166, EB-Verlag, Berlin.

Brager, G. \& Specht, H., 1973, Community organizing, Columbia University Press, New York, NY.

De Roest, H., 2013, 'Kirche in Grenzsituationen', in C. Aus der Au, R. Kunz, T. Schlag \& H. Strub (eds.), Urbanität und Öffentlichkeit: Kirche im Spannungsfeld gesellschaftlicher Dynamiken, pp. 75-86, TVZ, Zürich.

De Roest, H., 2017, 'Shaping a societal domain: The future of protestant theology', in G. Van den Brink \& G. Den Hertog (eds.), Protestant traditions and the soul of Europe, Beiheft zur Ökumenische Rundschau, pp. 275-288, Evangelische Verl.-Anstalt, Leipzig.
Eurich, J. \& Maaser, W., 2013, Diakonie in der Sozialökonomie: Studien zu Folgen der neuen Wohlfahrtspolitik, Ev. Verl.-Anstalt, Leipzig.

Grözinger, A., 1998, Die Kirche - ist sie noch zu retten?, Gütersloher Verl.-Haus, Gütersloh.

Haas, H.-S., 2012, 'Von Dienstleistern zu Service-Intermediären: Zur zukünftigen Rolle diakonischer Unternehmen im Sozialraum', in H. Schmidt \& K.D. Hildemann (eds.) Nächstenliebe und Organisation: Zur Zukunft einer polyhybriden Diakonie in zivilgesellschaftlicher Perspektive, pp. 257-270, Evangelische Verl.-Anstalt, Leipzig.

Halbe, J., 2016, 'Die Ortsgemeinde - mit fälligem Einsatz in die Vernetzung mit der Region', in Diakonie Texte, pp. 22-27, 05, Diakonie Deutschland, Evangelisches Werk für Diakonie und Entwicklung e. V., Evangelischer Bundesverband, Berlin.

Hauschildt, E. \& Pohl-Patalong, U., 2013, Kirche (Lehrbuch Praktische Theologie 4), Gütersloher Verl.-Haus, Gütersloh.

Hermelink, J., 2011, Kirchliche Organisation und das Jenseits des Glaubens: Eine praktisch-theologische Theorie der evangelischen Kirche, Gütersloher Verl.-Haus, Gütersloh.

Hofmann, B., 2016, 'Zivilgesellschaftliches Engagement von Diakonie und Kirche', in J. Eurich \& H. Schmidt (eds.), Diakonik: Grundlagen - Konzeptionen - Diskurse, pp. 220-241, Vandenhoeck \& Ruprecht, Göttingen.

Holzer, B., 2010, Netzwerke (Einsichten: Themen der Soziologie), Transcript-Verlag, Bielefeld.

Horstmann, M. \& Neuhausen, E., 2010, Mutig mittendrin: Gemeinwesendiakonie in Deutschland, A study from the Institute of Social Sciences of the EKD, Münster.

Körs, A. \& Nagel, A.-K., 2018, Local 'formulas of peace': Religious diversity and stateinterfaith governance, SAGE Publications, London.

Kötter, R., 2015, Das Land ist hell und weit: Leidenschaftliche Kirche in der Mitte der Gesellschaft, EB-Verlag, Berlin.

Langer, A., Eurich, J. \& Güntner, S., 2019, Innovation in social services: A systematising overview based on the EU research platform INNOSERV, Springer VS, Wiesbaden.

Prendergast, E.C., 2000, Parish leadership in transition: Exploring models of partnership, inclusivity and collaboration, ProQuest Dissertations Publishing, Claremont.

Sandu, F. \& Ioan, H., 2013, Religious affiliation and social action in the public space, Expert Projects Publishing, Saarbrücken.

Schlag, T., 2012, Öffentliche Kirche: Grunddimensionen einer praktisch-theologischen Kirchentheorie, TVZ, Zürich.

Sigrist, C., 2014, 'Gemeinde im sozialen Nahraum', in R. Kunz \& T. Schlag (eds.), Handbuch für Kirchen- und Gemeindeentwicklung, pp. 327-335, Neukirchener Verlag, Neukirchen-Vluyn.

Stövesand, S. \& Stoik, C., 2013, 'Gemeinwesen als Konzept Sozialer Arbeit - eine Einleitung', in S. Stövesand, C. Stoik \& U. Troxler (eds.), Handbuch Gemeinwesenarbeit: Traditionen und Positionen, Konzepte und Methoden Deutschland - Schweiz - Österreich (Theorie, Forschung und Praxis der Sozialen Arbeit 4), pp. 14-36, Verlag Barbara Budrich, Leverkusen. 